GIMENEZ, Charlise P. Colet; VERONESE, Osmar. O papel do vereador no Estado de Direito no Brasil: a defesa dos subsídios como equação democrática. Revista Eletrônica Direito e Política, Programa de Pós-Graduação Stricto Sensu em Ciência Jurídica da UNIVALI, Itajaí, v.10, n.2, $1^{\circ}$ quadrimestre de 2015. Disponível em: www.univali.br/direitoepolitica - ISSN 1980-7791.

\title{
O PAPEL DO VEREADOR NO ESTADO DE DIREITO NO BRASIL: A DEFESA DOS SUBSÍDIOS COMO EQUAÇÃO DEMOCRÁTICA ${ }^{1}$
}

\author{
THE COUNCILOR'S ROLE IN THE RULE OF LAW IN BRAZIL: THE DEFENSE \\ OF SUBSIDIES AS DEMOCRATIC EQUATION
}

\author{
Charlise P. Colet Gimenez ${ }^{2}$ \\ Osmar Veronese ${ }^{3}$
}

SUMÁRIO: Introdução. 1. Aspectos do surgimento e evolução da vereança no Brasil; 2. A defesa da vereança como serviço honorífico; 3. Subsídios e parâmetros constitucionais; 4. Razões para retribuir; Considerações finais; Referências das fontes citadas.

RESUMO: O presente estudo examina os subsídios dos vereadores à luz dos parâmetros constitucionais estabelecidos na Lei Fundamental brasileira. Após indicar a conexão entre os vereadores e o Parlamento moderno, o qual traz a marca institucional gestada na Revolução Francesa de 1789, busca-se definir a função da vereança e examinar o tratamento dispensado pelas diversas

\footnotetext{
${ }^{1}$ Ensaio produzido a partir das reflexões do projeto de pesquisa "Estado, Constituição e diferença: a proteção das minorias à luz do constitucionalismo contemporâneo", vinculado ao grupo de estudos "Novos Direitos na Sociedade Globalizada", da linha de pesquisa Direito e Multiculturalismo, do Mestrado em Direito da URI Santo Ângelo/RS, em interlocução com o Grupo de Estudos "A Tutela dos Direitos e sua Efetividade", também do Mestrado em Direito da URI Santo Ângelo/RS, registrado no CNPQ.

2 Doutoranda em Direito e Mestre em Direito pela UNISC - Universidade de Santa Cruz do Sul e Especialista em Direito Penal e Processo Penal pela UNIJUÍ - Universidade Regional do Noroeste do Estado do Rio Grande do Sul. Professora de Direito Penal e Estágio de Prática Jurídica pela URI Universidade Regional Integrada do Alto Uruguai e Missões (Santo Ângelo/RS). Membro do Grupo de Pesquisa "Políticas Públicas no Tratamento dos Conflitos" vinculado ao CNPq. Membro do Grupo de Estudos "A Tutela dos Direitos e sua Efetividade" vinculado ao CNPQ. Advogada. Bolsista CAPES. E-mail: charliseg@santoangelo.uri.br

3 Doutor em Direito Constitucional pela Universidad de Valladolid, ES, Professor de Direito Constitucional da Universidade Regional Integrada do Alto Uruguai e das Missões - URI (Graduação e Mestrado) e do Instituto Cenecista de Ensino Superior de Santo Ângelo (IESA), Santo Ângelo/RS, Procurador da República. Autor dos livros "Constituição: reformar para que(m)" e "Inviolabilidade parlamentar: do senador ao vereador", publicados pela Editora Livraria do Advogado. Email: osmarveronese@gmail.com
} 
GIMENEZ, Charlise P. Colet; VERONESE, Osmar. O papel do vereador no Estado de Direito no Brasil: a defesa dos subsídios como equação democrática. Revista Eletrônica Direito e Política, Programa de Pós-Graduação Stricto Sensu em Ciência Jurídica da UNIVALI, Itajaí, v.10, n.2, $1^{\circ}$ quadrimestre de 2015. Disponível em: www.univali.br/direitoepolitica - ISSN 1980-7791.

Constituições pátrias aos edis, em breve perspectiva histórica a auxiliar na compreensão do desenho dos parlamentares locais vertente na Constituição de 1988. Em relação a interrogação principal a que se propõe enfrentar o trabalho, parte-se dos argumentos dos defensores da vereança como serviço honorífico, passando pelos parâmetros normativos regentes da matéria, até chegar à defesa dos subsídios aos vereadores como equação democrática, decorrente dos mandados constitucionais e do modelo de Estado de Direito adotado pelo Brasil. Retribuir dignamente a quem trabalha para o público, longe de qualquer ilícito, além de ser medida de justiça é uma providência importante para combater a demagogia e afirmar as instituições democráticas.

Palavras-chave: Democracia; Parlamento; Vereadores; Subsídio

ABSTRACT: The present study analyzes the subsidies of councilors in the light of the constitutional parameters established in the Brazilian Fundamental Law. After pointing out the connection between the councilors and the modern Parliament, which brings the institutional brand gestated in the French Revolution of 1789, it defines the councliors' function and examines the treatment of the various Brazilian Constitutions to aldermen in a shortly historical perspective in order to help understanding the design of local parliamentary dimension in the 1988 Constitution. Considering the main question to which this paper proposes to answer, it is first detached the defense arguments that the councilors' activities are honorary service; then, it is demonstrated the regents normative parameters on this subjetct; at the end, it is argued the councilors' subsidies as democratic equation, due to the constitutional mandates and Rule of Law adopted by Brazil. It is a way to retribute dignity to those who work for the public, away from any illegal act, besides being a way of justice and an important way to combat demagogy and affirm democratic institutions.

Keywords: Democracy; Parliament; Councilors; Subsidy.

\section{INTRODUÇÃO}

O Estado Constitucional atual tem no parlamento sua gênese e espinha dorsal. Sem a Assembleia Nacional Francesa e sem os parlamentos posteriores, que nela se inspiraram, se poderia falar em alguma coisa, menos no Estado de Direito Constitucional. Em razão de sua centralidade e modo de funcionamento, não há outro organismo estatal em que a marcha político-institucional se reflita tão intensa e diretamente quanto no Parlamento. Tanto é assim que infindáveis crises têm conturbado o funcionamento das casas legislativas mundo afora, fenômeno reproduzido em alta intensidade pelas terras brasileiras. 
GIMENEZ, Charlise P. Colet; VERONESE, Osmar. O papel do vereador no Estado de Direito no Brasil: a defesa dos subsídios como equação democrática. Revista Eletrônica Direito e Política, Programa de Pós-Graduação Stricto Sensu em Ciência Jurídica da UNIVALI, Itajaí, v.10, n.2, $1^{\circ}$ quadrimestre de 2015. Disponível em: www.univali.br/direitoepolitica - ISSN 1980-7791.

O sistema representativo liberal ocidental seguidamente entra em rota de colisão com o pensamento dominante da sociedade moderna, ora sendo declarado obsoleto, ora sendo substituído por modelos corporativos, ora tendo suas funções esvaziadas, mas mesmo diante dos casos mais severos de aniquilamento, tal qual fênix, ressurge das cinzas e se fortalece, especialmente em países que se propõe a sedimentar práticas democráticas. Por mais que as crises façam plantão na porta dos parlamentos, sempre à espera de uma das várias oportunidades para desfilarem por seu nervoso sistema vascular, o parlamento livre sempre é uma possibilidade viva de controle dos governos e a garantia de legitimidade dos sistemas políticos.

O objeto aqui passa longe de estudar o parlamento e sua importância para a democracia hodierna, tampouco se propõe a examinar a conturbada história parlamentar brasileira, mas, sim, visa responder ao seguinte questionamento: é jurídica e politicamente defensável que os vereadores recebam remuneração com recursos públicos ou chegou a hora de implementar mandatos parlamentares municipais honoríficos? Antes de responder à interrogação, convém lançar um olhar sobre o vereador e seu evolver em solo pátrio.

\section{ASPECTOS DO SURGIMENTO E EVOLUÇÃO DA VEREANÇA NO BRASIL}

Etimologicamente, a palavra vereador, de verear, significa administrar, reger, governar. A origem remota é verea, forma arcaica de vereda ("caminho, estrada secundária"), de onde surgiu o verbo verear, com o significado primitivo de "administrar as estradas e os caminhos", "governar, reger a terra, pondo nela vereamento e boa polícia, bom regime". ${ }^{4}$ Pouco a pouco, os vereadores foram assumindo outras atividades ligadas ao bom funcionamento da comunidade, zelando pelo bem-estar e sossego dos Municípios. ${ }^{5}$ O dicionário de Morais, de 1813, já os conceitua como aqueles que cuidam de vários pontos importantes da

\footnotetext{
4 MELO FILHO, Urbano Vitalino de. Direito Municipal em movimento. Belo Horizonte: Del Rey, 1999, p. 51)

${ }^{5}$ SANTANA, Jair Eduardo. Tratado teórico e prático do vereador. Belo Horizonte: Del Rey, 1998, p. 29.
} 
GIMENEZ, Charlise P. Colet; VERONESE, Osmar. O papel do vereador no Estado de Direito no Brasil: a defesa dos subsídios como equação democrática. Revista Eletrônica Direito e Política, Programa de Pós-Graduação Stricto Sensu em Ciência Jurídica da UNIVALI, Itajaí, v.10, n.2, $1^{\circ}$ quadrimestre de 2015. Disponível em: www.univali.br/direitoepolitica - ISSN 1980-7791.

vida da coletividade, incluindo o conserto de estradas e de ruas, a supervisão do abastecimento de água e de víveres e a manutenção da limpeza e do asseio da cidade - como se vê, funções já bem parecidas com as de um vereador moderno. $^{6}$ No direito brasileiro atual, vereador é o legislador municipal, o membro da Câmara Municipal.

Historicamente, a figura e a função do edil aparecem em Portugal, no séc. XIV, onde o vereador servia de assistente aos juízes na administração municipal. Esses assistentes, por suas atribuições, assemelhavam-se ao "aedile", antigo magistrado romano que cuidava da salubridade, da desobstrução das vias públicas, da inspeção e conservação dos edifícios públicos, do abastecimento das cidades e que, vigiando o preço do trigo, os pesos e as medidas, protegia os compradores contra as fraudes, podendo, para tanto, editar os regulamentos edicilianos, depois chamados de posturas e, hoje, em solo brasileiro, leis municipais. $^{7}$

A vereança brasileira constitui a raiz primordial do Poder Legislativo em todo o continente americano, pois foi na antiga Capitania de São Vicente que surgiu a primeira Câmara Municipal das Américas. Quando Martim Afonso de Sousa, em 1532, instalou a Câmara de Vereadores de São Vicente, estabeleceu um marco do surgimento dos vereadores do Brasil, os quais tinham competência para discutir e deliberar sobre os problemas referentes ao arruamento, construções, limpeza, ordem pública, taxas e impostos, divisão e posse das terras e heranças, além de promover a guerra e assentar a paz com os gentios. ${ }^{8} \mathrm{Na}$ época préconstitucional, exerciam, juntamente como os juízes ordinários, eleitos pela Câmara, competência para julgamentos judiciais, gozando de amplas

\footnotetext{
${ }^{6}$ Definição estampada no site "sua língua" (<http://www.sualingua.com.br/02/02_eleicao2.htm> Acesso em: 24 abr. 2013), a qual, nos aspectos gerais, coincide com a presente nos dicionários de língua portuguesa.
}

7 TUMA, Romeu. In: Diário do Senado Federal. Brasília: Senado Federal, 14 de novembro de 2003.

${ }^{8}$ TUMA, Romeu. In: Diário do Senado Federal, p. 36874. 
GIMENEZ, Charlise P. Colet; VERONESE, Osmar. O papel do vereador no Estado de Direito no Brasil: a defesa dos subsídios como equação democrática. Revista Eletrônica Direito e Política, Programa de Pós-Graduação Stricto Sensu em Ciência Jurídica da UNIVALI, Itajaí, v.10, n.2, $1^{\circ}$ quadrimestre de 2015. Disponível em: www.univali.br/direitoepolitica - ISSN 1980-7791.

prerrogativas, a ponto de poderem se opor aos mais poderosos da terra, especialmente durante as reuniões, na Câmara. ${ }^{9}$

No Brasil colonial, à luz das Ordenações Filipinas, o exercício da vereança dos indicados e eleitos era obrigatório, o que implicava prestar fiança, ou seja, deixar seus próprios bens hipotecados em nome da Câmara. À época, para ser vereador, era preciso ser "homem-bom", entendido como tal o português de boa instrução e prestígio entre os habitantes, tarefa vedada aos estrangeiros, aos não católicos e aos trabalhadores braçais. As eleições para a Câmara aconteciam de três em três anos, sendo que a reeleição só era permitida após três anos do fim do mandato. ${ }^{10}$

Debruçando-se sobre os relatos históricos, verifica-se que as câmaras vigentes no período colonial brasileiro eram núcleos político-administrativos que exerciam funções paradoxais: de um lado, simbolizavam o poder central, sendo o rosto do colonizador, caminhando, normalmente, de mãos dadas com os coronéis, expressando a dominação e o despotismo; de outro, serviam de canal de expressão dos movimentos sociais, de órgão capaz de dar vazão ao descontentamento, de permitir a articulação de resistências. Servir ora de braço do poder econômico-político (dando visibilidade, inclusive, às suas cisões internas), ora de oposição a ele, potencializando as contrariedades e atos de rebeldia locais, foram verdadeiro signo das câmaras municipais brasileiras dessa época, cujos genes foram transmitidos às câmaras do período monárquico.

Importa assentar que o município no Brasil, em vez de ser obra do Estado, precedeo, sendo seu fundamento, não podendo ser considerado um brinde da metrópole ou uma oficiosidade dos donatários, mas um produto das necessidades da população, que se aglomerava e carecia de governo. O lento e sacrificado processo de levantar povoados, construir igrejas, fomentar o comércio e a agricultura, além de erguer baluartes para opor resistência ao gentio, era feito mais com o suor dos particulares

\footnotetext{
${ }^{9}$ SILVA, José Afonso da. Manual do vereador. São Paulo: Malheiros, 2004, p. 12.

${ }^{10}$ TUMA, Romeu. In: Diário do Senado Federal, p. 36874.
} 
GIMENEZ, Charlise P. Colet; VERONESE, Osmar. O papel do vereador no Estado de Direito no Brasil: a defesa dos subsídios como equação democrática. Revista Eletrônica Direito e Política, Programa de Pós-Graduação Stricto Sensu em Ciência Jurídica da UNIVALI, Itajaí, v.10, n.2, $1^{\circ}$ quadrimestre de 2015. Disponível em: www.univali.br/direitoepolitica - ISSN 1980-7791.

do que pela escassa mão dos governantes, sendo "o povo a abelha infatigável que mais trabalha na edificação social".11

A Constituição Imperial reservou um capítulo às câmaras municipais, às quais cabia o governo econômico e municipal das cidades e vilas. Na regulamentação, realizada por Lei Orgânica, em 1828, suas funções ficaram limitadas ao âmbito administrativo, com vedação ao exercício de função jurisdicional contenciosa. $\mathrm{Na}$ ampla enumeração do art. 66 desse diploma, aparece como tarefa principal a vigilância sobre os bens e obras do Conselho/Município e o exercício do governo econômico e do poder de polícia locais, além de outras funções como cuidar da manutenção dos caminhos públicos. O Ato Adicional à Constituição do Império, de agosto de 1834, marca o reforço das funções das províncias com consequente esvaziamento das municipais, algo revertido em parte com a Lei n. 105, de 1840, sem, no entanto, permitir que as câmaras tivessem, salvo casos isolados, papel relevante naquele período.

Com a proclamação da República e a transformação das antigas províncias em Estados Federados, esses absorveram as principais funções dos municípios, editando as leis orgânicas municipais, exceto o Estado do Rio Grande do Sul, onde cada Município mantinha lei própria, votada por seus vereadores.

A Constituição de 1934 (re)estabelece a autonomia municipal e com ela o Poder Legislativo, composto por vereadores eleitos diretamente pelos munícipes, os quais resultaram prestigiados nesse momento democrático da vida política brasileira. Embora a Constituição ditatorial de 1937 acenou com a valorização das funções dos vereadores, tanto que eles eram os principais eleitores de um seleto grupo que, indiretamente, elegeriam os deputados federais, elas jamais chegaram a ser exercidas nesse período de eclipse democrático.

A Constituição de 1946, considerada por muitos a "carta de alforria" dos municípios, fortaleceu-Ihes a autonomia e elevou os vereadores à condição de

${ }^{11}$ COUTINHO, Mario Maia. O pai do municipalismo. São Paulo: Patrimônio, 1962, p. 68-69. Tais informações estão contidas na monografia "O município", datada de 1883, de João de Azevedo Carneiro Maia, que a obra reproduz. 
GIMENEZ, Charlise P. Colet; VERONESE, Osmar. O papel do vereador no Estado de Direito no Brasil: a defesa dos subsídios como equação democrática. Revista Eletrônica Direito e Política, Programa de Pós-Graduação Stricto Sensu em Ciência Jurídica da UNIVALI, Itajaí, v.10, n.2, $1^{\circ}$ quadrimestre de 2015. Disponível em: www.univali.br/direitoepolitica - ISSN 1980-7791.

legisladores locais, ${ }^{12}$ propiciando uma das mais belas páginas da democracia brasileira, sombreada, a partir de 1964, com a ditadura militar, período em que a liberdade parlamentar não passou de ficção.

A atual Constituição, de 1988, deu nova roupagem aos municípios, elevando-os a entes federativos, fixando-Ihes expressas e amplas competências. Em nenhum outro momento da história brasileira, as tarefas pertencentes aos municípios foram tão extensas, com o Estado brasileiro paulatinamente descentralizado, com relevante sobrecarga de atividades na esfera local. Essa é mais uma amostra de que o modelo de Estado é um processo histórico a par de outros, que não se cristaliza numa fórmula acabada, estando em contínua mutação, cujos fins impelem-no para novos modos de estruturação. ${ }^{13}$

Além disso, nosso modelo de constitucionalismo alinha-se ao surgido depois da segunda guerra mundial, com acentuado acolhimento dos direitos humanos como um fato carregado de significação, plasmado na existência de textos universalmente aceitos, como a Declaração Universal de Direitos da ONU, e em listas de direitos fundamentais (coincidentes em si) que constituem o núcleo das Constituições dos sistemas jurídicos contemporâneos. ${ }^{14}$ Esse consenso hodierno sobre a matéria não significa que em nossa época desapareceram as discrepâncias éticas, mas que as diferenças se trasladaram a um plano distinto e agora concernem nas distintas maneiras de entender e de fundamentar os direitos humanos, os quais não são, assim, exatamente os mesmos para todos. ${ }^{15}$

Ao pensarmos os direitos humanos em uma perspectiva multifuncional, de direitos de defesa e imperativos de tutela, ${ }^{16}$ os direitos fundamentais operam como valores

\footnotetext{
12 SILVA, José Afonso da. Manual do vereador. São Paulo: Malheiros, 2004, p. 12.

${ }^{13}$ MIRANDA, Jorge. Manual de Direito Constitucional. Tomo I. Coimbra: Coimbra, 1997, p. 49.

${ }^{14} \mathrm{Em}$ relação à eficácia privada dos direitos fundamentais, tema que tem encantado a doutrina, ver BILBAO UBILLOS, Juan María. La eficacia de los Derechos Fundamentales frente a los particulares. Madrid: Centro de Estudios Políticos y Constitucionales, 1997 e BERNAL PULIDO, Carlos. El principio de proporcionalidad y los Derechos Fundamentales. Madrid: Centro de Estudios Políticos y Constitucionales, 2005.

${ }^{15}$ ATIENZA, Manuel. El sentido del Derecho. Barcelona: Ariel, 2003, p. 207-208.

${ }^{16}$ FELDENS, Luciano. Direitos Fundamentais e Direito Penal. Porto Alegre: Livraria do Advogado, 2008, p. 58.
} 
GIMENEZ, Charlise P. Colet; VERONESE, Osmar. O papel do vereador no Estado de Direito no Brasil: a defesa dos subsídios como equação democrática. Revista Eletrônica Direito e Política, Programa de Pós-Graduação Stricto Sensu em Ciência Jurídica da UNIVALI, Itajaí, v.10, n.2, $1^{\circ}$ quadrimestre de 2015. Disponível em: www.univali.br/direitoepolitica - ISSN 1980-7791.

objetivos fundamentais da comunidade, ${ }^{17}$ projetando efeitos irradiantes ou ordens permanentemente dirigidas ao Estado para que os concretize, em força dirigente e determinante, ${ }^{18}$ orientando todo o funcionamento do ordenamento jurídico (público e privado), reclamando prestações positivas (legais, administrativas e judiciais), de modo a transformar o outrora Leviatã em caminho pelo qual esses direitos podem se maximizar. ${ }^{19}$

É nesse contexto que se inserem os vereadores, depositários de novas funções ${ }^{20}$ (o que não os afasta, ao contrário, reforça a necessidade de que continuem a exercer as duas grandes tarefas históricas do parlamento demoliberal, de berço francês, que é legislar e fiscalizar) responsabilidades, garantias ${ }^{21}$.... Mas será que devem receber subsídios?

\section{A DEFESA DA VEREANÇA COMO SERVIÇO HONORÍFICO}

É comum ouvir a defesa de que alguns cargos políticos, especialmente a vereança, seja exercido sem qualquer retribuição pecuniária. Na época em que vivemos, de manifestações populares, em que a sociedade em rede nunca foi tão real, essas teses tendem a angariar imensas simpatias. E não apenas nas ruas há adeptos, mas até no Parlamento Federal, havendo a Proposta de Emenda Constitucional no 35/2012, subscrita por trinta Senadores, a qual prevê que "em Municípios de até cinquenta mil habitantes, os Vereadores não farão jus à

17 SARLET, Ingo Wolfgang. A eficácia dos Direitos Fundamentais. Porto Alegre: Livraria do Advogado, 2006, p. 165. Ver também, BOBBIO, Norberto. A era dos Direitos. Rio de Janeiro: Campus, 1992

${ }^{18}$ CANOTILHO, José Joaquim Gomes. Constituição dirigente e vinculação do legislador: contributo para a compreensão das normas constitucionais programáticas. Coimbra: Coimbra, 1994 , p. 365.

${ }^{19}$ FELDENS, Luciano. Direitos Fundamentais e Direito Penal, 2008, p. 61.

${ }^{20}$ A função parlamentar não pode ser circunscrita ao âmbito estrito das câmaras, dado o papel intermediário entre o Parlamento e os partidos políticos exercido pelos grupos parlamentares, e, portanto, o exercício das funções parlamentares não se circunscreve aos salões das câmaras, mas abrange todas as atividades realizadas com a presença política do Deputado no País (MANZELLA, Andrea. Il Parlamento. Bologna: Il Mulino, 1977, p. 188).

${ }^{21}$ Sobre as garantias ver CIOLO, Vittorio di. Il Diritto Parlamentare nella teorie e nella pratica. Aspetti generali e profili strutturali. Milan: Giuffre, 1980; TORON, Alberto Zacharias. Inviolabilidade penal dos vereadores. São Paulo: Saraiva, 2004; TOSI, Silvano. Diritto Parlamentare. Milano: Dott. A. Giuffré, 1993. 
GIMENEZ, Charlise P. Colet; VERONESE, Osmar. O papel do vereador no Estado de Direito no Brasil: a defesa dos subsídios como equação democrática. Revista Eletrônica Direito e Política, Programa de Pós-Graduação Stricto Sensu em Ciência Jurídica da UNIVALI, Itajaí, v.10, n.2, $1^{\circ}$ quadrimestre de 2015. Disponível em: www.univali.br/direitoepolitica - ISSN 1980-7791.

percepção de subsídios". Ao justificar a PEC 35, os Senadores afirmam que os vereadores serão considerados agentes honoríficos e passarão a assumir o cargo em razão de sua condição cívica, de sua honorabilidade ou capacidade profissional, comprometidos com a ética, o interesse público e o desenvolvimento local.

Não foram poucas as bravatas de parlamentares, no decorrer da história, abrindo mão de todas as garantias, num jogo de cena que politicamente pode ser interessante, mas juridicamente não deve produzir qualquer efeito.22 São verdadeiros gestos propagandísticos sem valor jurídico algum, não passando de meras opiniões,23 pois nem o parlamentar, nem a própria assembleia podem revogar a Constituição "no grito".

O posicionamento favorável à gratuidade se assenta em alguns argumentos, dentre eles os excessos levados a efeito por muitas câmaras de vereadores, particularmente em períodos nos quais não eram estabelecidos parâmetros máximos a afugentarem os abusos, na lembrança de momentos históricos em que a retribuição por esse serviço político/público prestado não existia, além de alguma escora no direito comparado. ${ }^{24}$

Ao revisitar a história brasileira, é fácil constatar a veracidade das premissas, ou seja, pipocam abusos remuneratórios efetivamente desproporcionais ao exercício

\footnotetext{
22 Por exemplo: caso do Deputado francês, Razimbaud, na sessão de 25 de fevereiro de 1907, que anunciou a renúncia da inviolabilidade, cujo propósito foi abortado pelo presidente da Câmara, aos argumentos de ser impossível a renúncia, e a justiça não deveria sequer levar em conta tal manifestação (BUGALLAL Y ARAUJO, Gabino. Inviolabilidad parlamentaria. Discurso leído en el acto de su recepción (15.5.1921). Madrid: Real Academia de Ciencias Morales y Políticas, 192, p. 574); outro caso da França, de 1862, quando o Tribunal Correcional de Reims, ao denegar a possibilidade de renúncia (da imunidade), afirmou ser a garantia de ordem pública, que o mandado do deputado confere, a quem está investido dele por seus concidadãos, obrigações e deveres de interesse geral, sendo inadmissível a "autorização" particular suprir a autorização do corpo legislativo (REGUERAL Y BAILLY, Salustino G. La inviolabilidad y la inmunidad. Madrid: Imprenta de la Viuda de Prudêncio Pérez, 1915, p. 47).

${ }^{23}$ MANZELLA, Andrea. Il Parlamento. Bologna: Il Mulino, 1977, p. 186.

${ }^{24}$ Sublinhe-se que, em alguns períodos medievais, sequer existiu Parlamento. Quando existiu, seu papel era de coadjuvante, não se assemelhando ao papel central, nuclear, exercido pelo Parlamento liberal. Essa mudança de patamar de poder do Parlamento deve ser levada em conta na leitura a ser feita de suas garantias. O Parlamento medieval era um instrumento de governo na mão do Rei (ZAGREBELSKY, Gustavo. Le immunità parlamentari. Natura e limiti de una garanzia constituzionale. Turin: Einaudi, 1979, p. 5.)
} 
GIMENEZ, Charlise P. Colet; VERONESE, Osmar. O papel do vereador no Estado de Direito no Brasil: a defesa dos subsídios como equação democrática. Revista Eletrônica Direito e Política, Programa de Pós-Graduação Stricto Sensu em Ciência Jurídica da UNIVALI, Itajaí, v.10, n.2, $1^{\circ}$ quadrimestre de 2015. Disponível em: www.univali.br/direitoepolitica - ISSN 1980-7791.

da vereança, mormente em pequenas comunas, ${ }^{25}$ até casos recentes, com o Judiciário declarando a inconstitucionalidade da gratificação natalina ${ }^{26}$.

Da mesma forma, determinados períodos históricos não contaram com vereadores remunerados, entre os quais, a última significativa alteração acerca da existência ou não do direito à remuneração se deu a partir da Constituição de 1967, a qual previa esse direito somente aos vereadores pertencentes aos municípios com mais de cem mil habitantes, previsão elevada para duzentos mil, por força do Ato Institucional n. 07, de 26 de fevereiro de 1969²7. A Emenda Constitucional n. 4, de 23 de abril de 1975, estendeu esse direito a todos os vereadores brasileiros, previsão atualmente vigente, com mudanças de nomenclatura que não possuem maior importância para a abordagem aqui proposta.

Há também, os exemplos do direito comparado, como a referência ao modelo uruguaio, em que o art. 295 da Constituição prevê serviços honoríficos, ao sistema inglês..., comparações perigosas, na medida em que tendem a considerar iguais situações muito desiguais, seja em relação ao sistema jurídico, seja em relação às condições fáticas.

Esses argumentos, ao lado de outros, mesmo com risco de alinhamento a uma corrente de pensamento minoritária, não merecem prosperar pelas razões a seguir alinhavadas.

\footnotetext{
${ }^{25}$ A Corte Suprema brasileira, por diversas oportunidades, enfrentou a questão, seja asseverando que "a remuneração dos vereadores está sujeita ao teto, considerada a do prefeito" (STF, RE 181.715, 1997; RE 220.006-8/SP, 1998), seja invalidando regra municipal que concedia aos exprefeitos subsídio vitalício, ao argumento de que isso é matéria a ser cuidada exclusivamente por norma constitucional federal (STF, Inf. n. 143, 1999), em clara contenção de abusos.

${ }^{26}$ Ação Direta de Inconstitucionalidade no 70038566675, Tribunal Pleno, Tribunal de Justiça do RS, Relator: Orlando Heemann Júnior, Julgado em 23/1/2012.

${ }^{27}$ Art. 15, § 20, da Constituição de 1967-1969.
} 
GIMENEZ, Charlise P. Colet; VERONESE, Osmar. O papel do vereador no Estado de Direito no Brasil: a defesa dos subsídios como equação democrática. Revista Eletrônica Direito e Política, Programa de Pós-Graduação Stricto Sensu em Ciência Jurídica da UNIVALI, Itajaí, v.10, n.2, $1^{\circ}$ quadrimestre de 2015. Disponível em: www.univali.br/direitoepolitica - ISSN 1980-7791.

\section{SUBSÍDIOS E PARÂMETROS CONSTITUCIONAIS}

Os excessos cometidos pelos legisladores municipais foram determinantes para o estabelecimento de uma série de critérios constitucionais destinados a enquadrar proporcionalmente a retribuição pelo múnus exercido. Para se ter uma ideia da controvérsia do tema, a primeira Emenda à Constituição de 1988, datada de 31 de março de 1992, cuidava justamente da retribuição aos deputados estaduais e aos vereadores, fixando limites máximos. Enquanto aqueles poderiam receber no máximo setenta e cinco por cento da remuneração em espécie dos deputados federais, estes tiveram como teto setenta e cinco por cento da remuneração em espécie dos deputados federais. Além disso, o total da despesa com a remuneração dos vereadores não poderia ultrapassar o montante de cinco por cento da receita do Município. ${ }^{28}$

O regramento atual é fruto das Emendas Constitucionais no 25, de 2000, e no 41, de 2003, as quais superaram, em parte, tanto a redação da Emenda $n^{\circ} 1$, como a no 19, ambas cuidando da matéria. A retribuição pecuniária aos vereadores pelos serviços prestados, denominada subsídio, encontra na Constituição os seguintes critérios de fixação: terá por parâmetro o subsídio dos deputados estaduais; não será superior a do prefeito; ${ }^{29}$ deverá obedecer proporcionalmente ao número de habitantes do Município, de modo que os vereadores dos municípios menores tenham remuneração menor; ${ }^{30}$ será fixado

\footnotetext{
${ }^{28}$ A Emenda Constitucional n. 1, de 31/3/1992, introduziu essas inovações nos arts. 27, § 20, e 29, VI e VII, da Constituição Federal.

${ }^{29}$ Constituição Federal, art. 37, XI: "- a remuneração e o subsídio dos ocupantes de cargos, funções e empregos públicos da administração direta, autárquica e fundacional, dos membros de qualquer dos Poderes da União, dos Estados, do Distrito Federal e dos Municípios, dos detentores de mandato eletivo e dos demais agentes políticos e os proventos, pensões ou outra espécie remuneratória, percebidos cumulativamente ou não, incluídas as vantagens pessoais ou de qualquer outra natureza, não poderão exceder o subsídio mensal, em espécie, dos Ministros do Supremo Tribunal Federal, aplicando-se como limite, nos Municípios, o subsídio do Prefeito...".

${ }^{30}$ A Constituição Federal, no art. 29, inc. VI, estatui as seguintes limitações: "a) em Municípios de até dez mil habitantes, o subsídio máximo dos Vereadores corresponderá a vinte por cento do subsídio dos Deputados Estaduais; b) em Municípios de dez mil e um a cinquenta mil habitantes, o subsídio máximo dos Vereadores corresponderá a trinta por cento do subsídio dos Deputados Estaduais; c) em Municípios de cinquenta mil e um a cem mil habitantes, o subsídio máximo dos Vereadores corresponderá a quarenta por cento do subsídio dos Deputados Estaduais; d) em Municípios de cem mil e um a trezentos mil habitantes, o subsídio máximo dos Vereadores corresponderá a cinquenta por cento do subsídio dos Deputados Estaduais; e) em Municípios de trezentos mil e um a quinhentos mil habitantes, o subsídio máximo dos Vereadores corresponderá
} 
GIMENEZ, Charlise P. Colet; VERONESE, Osmar. O papel do vereador no Estado de Direito no Brasil: a defesa dos subsídios como equação democrática. Revista Eletrônica Direito e Política, Programa de Pós-Graduação Stricto Sensu em Ciência Jurídica da UNIVALI, Itajaí, v.10, n.2, $1^{\circ}$ quadrimestre de 2015. Disponível em: www.univali.br/direitoepolitica - ISSN 1980-7791.

\section{pela Câmara de Vereadores sempre para o período subsequente, ${ }^{31}$ evitando} autoconcessões, mas assegurada revisão anual; sofrerá incidência ${ }^{32}$ tributária; $^{33}$ o total da despesa com remuneração dos vereadores não poderá ultrapassar cinco por cento da receita do Município; ${ }^{34}$ o total da despesa do Poder Legislativo municipal também encontra vários limites constitucionalizados. ${ }^{35}$

a sessenta por cento do subsídio dos Deputados Estaduais; f) em Municípios de mais de quinhentos mil habitantes, o subsídio máximo dos Vereadores corresponderá a setenta e cinco por cento do subsídio dos Deputados Estaduais; VII - o total da despesa com a remuneração dos Vereadores não poderá ultrapassar o montante de cinco por cento da receita do Município".

${ }^{31}$ Constituição Federal, art. 29, VI, caput: "o subsídio dos Vereadores será fixado pelas respectivas Câmaras Municipais em cada legislatura para a subsequente, observado o que dispõe esta Constituição, observados os critérios estabelecidos na respectiva Lei Orgânica e os seguintes limites máximos".

${ }^{32}$ A combinação do art. 29, incisos V e VI, da Constituição Federal, representa a superação constitucional de um período em que determinados agentes políticos detinham o privilégio de não serem alcançados pelas garras tributárias estatais, algo a ferir um dos valores nucleares do Estado Constitucional de Direito, a saber, o princípio da igualdade. O atual texto constitucional igualou aqueles que sempre deveriam ter recebido tratamento tributário igual, quer dizer, o imposto sobre rendas e proventos de qualquer natureza deve incidir sobre o percebido pelos Vereadores e demais agentes políticos, em consonância com o expresso na Constituição: "Art. 150. Sem prejuízo de outras garantias asseguradas ao contribuinte, é vedado à União, aos Estados, ao Distrito Federal e aos Municípios: [...] II - instituir tratamento desigual entre contribuintes que se encontrem em situação equivalente, proibida qualquer distinção em razão de ocupação profissional ou função por eles exercida, independentemente da denominação jurídica dos rendimentos, títulos ou direitos".

33 Os privilégios tributários estabelecidos em favor de detentores de cargos públicos não foram exclusividade brasileira, reproduzindo-se, por exemplo, no Uruguai, onde os legisladores e outros governantes importavam seus automóveis sem pagar impostos, situação que popularmente se conhecia como "ley de autos baratos", ou "ley de los colachatas", possibilidade agora vedada pelo art. 117, in fine, da Constituição uruguaia, que estabelece: "Dicha compensación les será satisfecha con absoluta independencia del Poder Ejecutivo y fuera de ella, los Legisladores no podrán recibir beneficios económicos de ninguna naturaleza que deriven del ejercicio de su cargo".

${ }^{34}$ A receita do Município é toda a entrada que integra seu patrimônio, compondo-se de rendas próprias (tributos e preços) e demais recursos financeiros (transferências públicas e privadas, como participação em receita de outra entidade) destinados à realização de seus fins, excetuados depósitos e cauções. Cuida-se da receita estimada, não realizada, na forma prevista na Lei $\mathrm{n}$. 4.320/64 (SILVA, José Afonso da. Manual do vereador. São Paulo: Malheiros, 2004, p. 78).

35 Art. 29-A. O total da despesa do Poder Legislativo Municipal, incluídos os subsídios dos Vereadores e excluídos os gastos com inativos, não poderá ultrapassar os seguintes percentuais, relativos ao somatório da receita tributária e das transferências previstas no § 50 do art. 153 e nos arts. 158 e 159, efetivamente realizado no exercício anterior: I - 7\% (sete por cento) para Municípios com população de até 100.000 (cem mil) habitantes; II - 6\% (seis por cento) para Municípios com população entre 100.000 (cem mil) e 300.000 (trezentos mil) habitantes; III - 5\% (cinco por cento) para Municípios com população entre 300.001 (trezentos mil e um) e 500.000 (quinhentos mil) habitantes; IV - 4,5\% (quatro inteiros e cinco décimos por cento) para Municípios com população entre 500.001 (quinhentos mil e um) e 3.000.000 (três milhões) de habitantes; $V$ $4 \%$ (quatro por cento) para Municípios com população entre 3.000.001 (três milhões e um) e 8.000.000 (oito milhões) de habitantes; VI - 3,5\% (três inteiros e cinco décimos por cento) para Municípios com população acima de 8.000 .001 (oito milhões e um) habitantes. $\S 1$ o A Câmara Municipal não gastará mais de setenta por cento de sua receita com folha de pagamento, incluído o gasto com o subsídio de seus Vereadores. 
GIMENEZ, Charlise P. Colet; VERONESE, Osmar. O papel do vereador no Estado de Direito no Brasil: a defesa dos subsídios como equação democrática. Revista Eletrônica Direito e Política, Programa de Pós-Graduação Stricto Sensu em Ciência Jurídica da UNIVALI, Itajaí, v.10, n.2, $1^{\circ}$ quadrimestre de 2015. Disponível em: www.univali.br/direitoepolitica - ISSN 1980-7791.

Em relação ao tema, o constituinte foi tão criterioso que chegou a exagerar, ingressando em campos materiais que bem poderiam ter sido cuidados por lei. Esse aparente excesso de zelo pode ser compreendido no contexto brasileiro, cujos abusos tornam arriscadas previsões genéricas ou a fixação de limites somente em leis infraconstitucionais. Com a consolidação da democracia e a solidificação das instituições, em futuro que se espera próximo, quem sabe a Lei Maior possa "emagrecer" no trato da matéria em epígrafe, sem maior risco.

Respeitando as balizas constitucionais, caberá à Câmara Municipal de Vereadores fixar, por lei $^{36}$ específica, ${ }^{37}$ o subsídio dos futuros edis, visto que a fixação será sempre para o período subsequente, ${ }^{38}$ assegurando-se revisão anual. Enquanto

\begin{abstract}
${ }^{36}$ Embora a edição de Resolução, aprovada na forma regimental, foi a espécie normativa utilizada, por algum tempo, para a fixação dessa retribuição - para parte da doutrina, a Resolução se presta a cuidar assuntos de interesse interno das Câmaras, enquanto o Decreto-Legislativo trata de questões de efeitos externos, entendimento acolhido em algumas Leis Orgânicas, como a de Santo Ângelo (art. 55, XIV: "deliberar, mediante resolução, sobre assuntos de ordem interna e nos casos de sua competência externa, por meio de decreto legislativo"), mas que não pode ser tomada como absoluta, no âmbito pátrio, na medida em que várias resoluções produzem efeitos externos à Casa editora, como as resoluções que suspendem uma lei declarada inconstitucional pelo Supremo Tribunal Federal, as que autorizam o Executivo a elaborar Lei Delegada..., - atualmente prevalece o entendimento de que o tema há de ser tratado por lei específica.
\end{abstract}

$37 \mathrm{Na}$ linha introduzida pela Emenda Constitucional n. 19, de 1998, que deu nova redação ao art. $37, \mathrm{X}$, da Constituição, passou-se a exigir, para tanto, a edição de lei específica, verbis: "a remuneração dos servidores públicos e o subsídio de que trata o § $4^{\circ}$ do art. 39 somente poderão ser fixados ou alterados por lei específica, observada a iniciativa privativa em cada caso, assegurada revisão geral anual, sempre na mesma data e sem distinção de índices".

38 O STF reforçou esse entendimento ao julgar a ADI 3833, assentando: "o modelo ou veículo de deliberação a que pode recorrer o Congresso Nacional para fixar estipêndios de todo parlamentar federal é a lei ordinária. Lei formal do Congresso Nacional, que ainda se caracterize pela sua especificidade. Logo, 'lei específica' ou monotemática, a se revelar como instrumento deliberativo de máxima densidade material e interesse coletivo, por isso que exigente de mais centrada atenção dos legisladores em sessão plenária e mais facilitado acompanhamento popular. [...] 0 subsídio mencionado naquela norma é o que há de ser atribuído ao membro de poder, o qual deverá ser fixado, exclusivamente em parcela única, e por lei específica, quer dizer, lei em sentido formal, fruto do devido processo legislativo, não podendo ser substituído por norma de outra categoria, tal como se estampa no caso apreciado nesta medida cautelar [...] Isso significa que a matéria não pode ser regulada por ato - como disse - das Mesas do Senado Federal e da Câmara dos Deputados, ainda que genericamente previstas num decreto legislativo, devendo ser objeto de apreciação por parte do Plenário de ambas as Casas. E realmente não se pode admitir, pelo menos num juízo preliminar, a edição de um decreto genérico, porque toda vez que a Constituição cogita da fixação dos subsídios e vencimentos, fala em lei específica, afastando, a possibilidade de edição de um ato genérico, porque a cidadania quer saber, em quanto os membros de Poder e os servidores serão aumentados" (...) O constituinte pretendeu evitar que alguma categoria de servidores ou de membros do Poder apresentasse em cheque diretamente na boca do caixa do erário, sem qualquer previsão, mediante um ato administrativo, um ato interno, sem que fosse submetido ao crivo dos representantes do povo que são aqueles autorizados a aumentar subsídios e vencimentos". Na mesma linha: ADI 3.831-MC, Rel. Min. Cármen Lúcia, julgamento em 15-1206, DJ de 3-8-07; ADI 3.369-MC, Rel. Min; Carlos Velloso, julgamento em 16-12-04, DJ de 10-205. 
GIMENEZ, Charlise P. Colet; VERONESE, Osmar. O papel do vereador no Estado de Direito no Brasil: a defesa dos subsídios como equação democrática. Revista Eletrônica Direito e Política, Programa de Pós-Graduação Stricto Sensu em Ciência Jurídica da UNIVALI, Itajaí, v.10, n.2, $1^{\circ}$ quadrimestre de 2015. Disponível em: www.univali.br/direitoepolitica - ISSN 1980-7791.

algumas Leis Orgânicas preveem o percebimento de uma parcela única, outras compatibilizam parcela fixa e variável, critério este defendido por alguns doutrinadores, $^{39}$ mas que deve ser evitado, em nome da transparência da gestão pública e no propósito de manter harmonia com o texto constitucional, que prevê a fixação do subsídio em "parcela única". ${ }^{40}$

Atente-se que a previsão constitucional federal de subsídio não estabelece uma faculdade, mas um direito constitucional irrenunciável, de modo a não terem as câmaras municipais possibilidade de estabelecer a gratuidade do mandato. ${ }^{41}$ Após recebido o subsídio, não há impedimento de o parlamentar abrir mão do valor, ou restituindo ao erário, ou destinando para alguma entidade, na maioria dos casos, prestadora de assistência social. Essas doações, a bem da verdade, se revelam assistencialistas e demagógicas, custando caro à sociedade, visto serem feitas por quem possui outros meios de sobrevivência, não necessitando dessa remuneração para sobreviver, além de entabular compromissos eleitorais, mesmo não expressos, criando uma espécie de dívida a ser solvida por votos, em flagrante atentado à lisura das eleições. Nada contra doações para entidades que prestam serviços relevantes à comunidade, feita por pessoas físicas ou jurídicas, mas as doações de subsídios, normalmente feitas sob holofotes, deveriam ser proibidas, por produzirem graves malefícios.

\footnotetext{
${ }^{39}$ SILVA, José Afonso da. Manual do vereador. São Paulo: Malheiros, 2004, p. 12.

${ }^{40}$ Constituição Federal, art. 39, § $4^{\circ}$. O referido dispositivo constitucional remete ao art. $37, \mathrm{X} \mathrm{e}$ $\mathrm{XI}$, ainda carente de uma interpretação sólida, o que não invalida o afirmado. Excepciona-se o pagamento de diárias, que reembolsam despesas realizadas com viagens fora da sede destinada ao exercício da vereança, por não se constituírem vantagem pecuniária em razão do mandato. Sobre o tema: "O dispositivo básico para se entender a ideia de subsídio é o \& 40 do artigo 39, introduzido pela Emenda Constitucional n. 19/98, que o prevê como 'parcela única vedado o acréscimo de qualquer gratificação, adicional, abono, prêmio, verba de representação ou outra espécie remuneratória, obedecido, em qualquer caso, o disposto no artigo 37, X e XI'. Ao falar em parcela única, fica clara a intenção de vedar a fixação dos subsídios em duas partes, uma fixa e outra variável, tal como ocorria com os agentes políticos na vigência da Constituição de 1967. E, ao vedar expressamente o acréscimo de qualquer gratificação, adicional, abono, prêmio, verba de representação ou outra espécie remuneratória, também fica clara a intenção de extinguir, para as mesmas categorias de agentes públicos, o sistema remuneratório que vem vigorando tradicionalmente na Administração Pública e que compreende o padrão fixado em leis mais as vantagens pecuniárias de variada natureza previstas na legislação estatutária. Com isso, ficam derrogadas, para os agentes que percebam subsídios, todas as normas legais que prevejam vantagens pecuniárias como parte da remuneração" (DI PIETRO, Maria Sylvia Zanella. Direito
} Administrativo. 18 ed. São Paulo: Atlas, 2005, p. 496).

${ }^{41}$ SILVA, José Afonso da. Manual do vereador. São Paulo: Malheiros, 2004, p. 12. 
GIMENEZ, Charlise P. Colet; VERONESE, Osmar. O papel do vereador no Estado de Direito no Brasil: a defesa dos subsídios como equação democrática. Revista Eletrônica Direito e Política, Programa de Pós-Graduação Stricto Sensu em Ciência Jurídica da UNIVALI, Itajaí, v.10, n.2, $1^{\circ}$ quadrimestre de 2015. Disponível em: www.univali.br/direitoepolitica - ISSN 1980-7791.

A respeito da retribuição pelo exercício da função parlamentar municipal, vale examinar a ação ${ }^{42}$ proposta pelo Diretório Municipal do Partido dos Trabalhadores de Campinas do Sul, requerendo a declaração de inconstitucionalidade da Lei Municipal n. 1.401, de 28-9-2004, a qual previa que os edis deveriam prestar serviço de relevante valor social e gratuito para a legislatura 2005-2008, não tendo direito a perceber subsídios de qualquer espécie pela atuação parlamentar. $^{43}$

Afora os aspectos formais, interessa o foco material aduzido pelo proponente, para quem a determinação de subsídio igual a zero vai de encontro aos princípios da impessoalidade, moralidade e razoabilidade, asseverando que o regramento constitucional não se reporta a qualquer ajuda de custo, mas apenas consigna que o subsídio deve ${ }^{44}$ ser fixado nos termos do art. 39, § 40.45

Mesmo considerando a possível obediência ao processo legislativo, aspecto ressaltado na decisão, o Poder Judiciário perdeu a oportunidade de interceptar medida tão esdrúxula, desproporcional, sempre envolvida em demagogia e afrontadora do modelo atual de Estado, em prática incompatível com a democracia moderna que com tanto esforço se quer construir.

42 TJRS: ADI. n. 70013817986, Órgão Especial, Rel. Luiz Ari Azambuja Ramos, J. 26.6.2006.

${ }^{43}$ Lei n. 1401/2004: "Fixa os subsídios dos Vereadores de Campinas do Sul e dá outras providências - Carlos Alberto Corbelini, Prefeito de Campinas do Sul, Estado do Rio Grande do Sul, no uso das atribuições que Ihe são conferidas pela Lei Orgânica do Município e tendo em vista a iniciativa da Câmara Municipal de Vereadores de Campinas do Sul conforme disposto no Art. 29, incisos VI e 37, inciso X, todos da Constituição Federal e Art. 11 da Constituição Estadual; Faço saber que a Câmara de Campinas do Sul aprovou e eu sanciono e promulgo a seguinte Lei: Art. 10 - Os Vereadores da Câmara Municipal de Vereadores de Campinas do Sul, para a Legislatura de 2005 a 2008, prestarão serviço de relevante valor social e gratuito, não tendo direito a perceber subsídios de qualquer espécie por sua atuação parlamentar. Art. $2^{\circ}$ - Durante o recesso quando convocados para sessões extraordinárias, a câmara de vereadores somente deliberará sobre matéria da convocação e não terão os Vereadores direitos a recebimento de parcela indenizatória. Art. 30 - Os Vereadores terão direito ao ressarcimento pelas despesas diárias e viagens regularmente comprovadas, de acordo com a legislação vigente. Art. 40 - As despesas decorrentes desta Lei correrão por conta da dotação orçamentária própria. Art. $5^{\circ}$ - Esta Lei entre em vigor na data de sua publicação, revogando a Resolução Legislativa 003/2004 de 11 de maio de 2004, produzindo seus efeitos a partir de $1^{\circ}$ de janeiro de 2005".

${ }^{44}$ Constituição Federal, art. 29:: "O Município reger-se-á por lei orgânica... atendidos... os seguintes preceitos: VI - o subsídio dos Vereadores será fixado pelas respectivas Câmaras Municipais em cada legislatura para a subsequente.."

45 Lei Fundamental, art. 39: "A União, os Estados, o Distrito Federal e os Municípios instituirão[...] $\S 40$ O membro de Poder, o detentor de mandato eletivo, os Ministros de Estado e os Secretários Estaduais e Municipais serão remunerados exclusivamente por subsídio fixado em parcela única $[\ldots]^{\prime \prime}$. 
GIMENEZ, Charlise P. Colet; VERONESE, Osmar. O papel do vereador no Estado de Direito no Brasil: a defesa dos subsídios como equação democrática. Revista Eletrônica Direito e Política, Programa de Pós-Graduação Stricto Sensu em Ciência Jurídica da UNIVALI, Itajaí, v.10, n.2, $1^{\circ}$ quadrimestre de 2015. Disponível em: www.univali.br/direitoepolitica - ISSN 1980-7791.

Quem trabalha de graça é escravo, quem se dedica ao público deve ser proporcionalmente remunerado, sob pena de acentuar a estratificação social, com as câmaras legislativas sendo fechadas aos pobres, ou os forçando à corrupção, em possível afronta até mesmo ao princípio da dignidade humana. Ainda que as reuniões sejam escassas e o Município seja pequeno, não há justificativa para impor aos edis a prestação de atividade gratuita, ${ }^{46}$ em afronta aos comandos legais cogentes, visto espancar qualquer lógica que, ao atenderem ao dever constitucional de fixar subsídio, estabeleçam sua inexistência, esvaziando o referido comando. Ademais, os vereadores fizeram demagogia com direito alheio, visto terem determinado que os sucessores ${ }^{47}$ é que trabalhariam de graça!

\section{RAZÕES PARA RETRIBUIR}

A gratuidade do mandado legislativo é incompatível com a democracia moderna, já dizia Miceli, em 1913. ${ }^{48}$ A retribuição pecuniária aos representantes do povo pelo exercício da função pública é uma medida justa e necessária em uma sociedade que abandonou, há tempo, "la vieja tesis del mandato representativo gratuito, propia del Estado Liberal". ${ }^{49}$

Primeiro, sem essa remuneração o poder seria monopólio dos ricos, dos que não a necessitam, ou pelo fato de serem individualmente afortunados, afastando-se de seus afazeres, levando ao parlamento a defesa de seus interesses e

\footnotetext{
${ }^{46}$ Nas razões de decidir pela constitucionalidade da lei municipal acima citada, constata-se algum desconforto com a situação e a indicação de possíveis caminhos jurídicos de remediá-la: " $A$ questão poderia ser solvida, quiçá - e aqui se está no âmbito apenas da conjectura -, com uma ação indenizatória contra o Município, por aquele vereador que se sentisse tolhido no direito à perceber contraprestação pecuniária pela vereança, hipótese que a lei antiga poderia servir, então sim, como parâmetro indenizatório, como referência pecuniária para aferir-se o montante da reparação, mesmo tendo esgotado seu prazo de vigência".

47 Constituição Estadual do RS, art. 11: "A remuneração do Prefeito, Vice-Prefeito e dos Vereadores será fixada pela Câmara Municipal, em cada legislatura para a subsequente, em data anterior à realização das eleições para os respectivos cargos, observado o que dispõe a Constituição Federal."

${ }^{48}$ MICELI apud MAXIMILIANO, Carlos. Commentários à Constituição brasileira de 1891. Rio de Janeiro: Jacinto Ribeiro dos Santos, 1918, p. 303
}

${ }^{49}$ DURÁN ALBA, Juan Fernando. Teoría general y régimen jurídico de las incompatibilidades parlamentarias en España. Madrid: Congreso de los Diputados, 2001, p. 514. 
GIMENEZ, Charlise P. Colet; VERONESE, Osmar. O papel do vereador no Estado de Direito no Brasil: a defesa dos subsídios como equação democrática. Revista Eletrônica Direito e Política, Programa de Pós-Graduação Stricto Sensu em Ciência Jurídica da UNIVALI, Itajaí, v.10, n.2, $1^{\circ}$ quadrimestre de 2015. Disponível em: www.univali.br/direitoepolitica - ISSN 1980-7791.

dispensando qualquer retribuição pública direta, ou por serem financiados por grandes empresas, cujos interesses pautarão sua atuação no mandado representativo (de quem?). Assim, resulta evidente que o abandono, mesmo que não integral, das atividades particulares para cuidar dos negócios públicos, merece ser compensada, até pelo pressuposto de que todo trabalho deve ser remunerado.

Segundo, o não recebimento de remuneração é potencialmente capaz de vulnerar a função, deixando o eleito mais suscetível de "cair em tentação", quer dizer, facilita a corrupção. Caso receber do público, em tese possuirá um compromisso público maior, estando menos sujeito à venda das convicções. Em recebendo do privado, direta ou disfarçadamente, entabulará compromissos antes com o privado. Não faz falta o subsídio a quem transforma a função legislativa em balcão de toda sorte de negócios. ${ }^{50} \mathrm{Na}$ melhor das hipóteses, a existência de partidos fortes poderia sustentar uma atuação parlamentar independente, o que não é o caso do Brasil, cujos partidos fortes são, na maioria dos casos, amplamente endividados, comprometendo-se, em algumas situações, com a defesa de interesses divorciados do público e do ético. ${ }^{51}$

Terceiro, nem sempre a fortuna sorri à capacidade intelectual e à inteireza de caráter, de modo que a falta de meios de sustentação tenderia a afastar da disputa os maiores talentos, probos e sinceros, e a produzir câmaras repletas de políticos profissionais, no pior dos sentidos. Assim como a riqueza não é título de capacidade, a pobreza não pode ser causa que inabilite. ${ }^{52}$ Os próprios incorruptíveis, aceitando a investidura, provavelmente seriam desleixados, atentos a outros interesses, pegos de surpresa nos debates das questões mais

\footnotetext{
${ }^{50}$ MAXIMILIANO, Carlos. Commentários à Constituição brasileira de 1891, 1918, p. 303.

${ }^{51}$ Veja-se, por exemplo, o caso do "mensalão", neologismo pelo qual ficou conhecido o esquema de corrupção de parlamentares que, conforme narrado na denúncia oferecida pelo Procurador-Geral da República, receberiam, mensalmente, propina para apoiarem o Governo Federal. Ao todo, foram denunciadas 40 pessoas, dentre políticos, empresários, publicitários e doleiros, pela pratica dos crimes de formação de quadrilha (22 suspeitos), corrupção ativa (11 suspeitos), corrupção passiva (13 suspeitos), lavagem de dinheiro (34 suspeitos), evasão de divisas (12 suspeitos), peculato (11 suspeitos) e falsidade ideológica (1 suspeito), boa parte deles condenados (Inq. 2245).

52 PÉREZ SERRANO apud FERNÁNDEZ-MIRANDA Y CAMPOAMOR, Alfonso. Las prerrogativas parlamentarias de inviolabilidad y inmunidad. In: ALZAGA VILLAAMIL, Oscar (coord.). Comentarios a las leyes políticas. Madrid: Editoriales de Derecho Reunidas, 1989. V. 6, p. 327.
} 
GIMENEZ, Charlise P. Colet; VERONESE, Osmar. O papel do vereador no Estado de Direito no Brasil: a defesa dos subsídios como equação democrática. Revista Eletrônica Direito e Política, Programa de Pós-Graduação Stricto Sensu em Ciência Jurídica da UNIVALI, Itajaí, v.10, n.2, $1^{\circ}$ quadrimestre de 2015. Disponível em: www.univali.br/direitoepolitica - ISSN 1980-7791.

importantes por falta de tempo para se dedicarem ao exercício da função pública. ${ }^{53}$

Quarto, é ilusória a crença de que a gratuidade é capaz de aportar prestígio e respeitabilidade ao parlamentar. Há muitos cargos e funções públicas exercidas na maioria dos países, remuneradas e prestigiadas, como magistrados, membros do Ministério Público, de modo a não haver qualquer relação direta entre alteridade popular do exercício de determinada função e retribuição pública.

Quinto, embora uma provável pesquisa de opinião pública tenda a indicar a contrariedade do povo ao pagamento dos vereadores pelo exercício da função, ${ }^{54}$ é preciso reconhecer que a história está repleta de exemplos de remuneração parlamentar desde Atenas ${ }^{55}$ até a França e os Estados Unidos, ${ }^{56}$ verdadeiros modelos democráticos a inspirarem outros sistemas assemelhados. Já no começo do século passado, Bugallal defendia a retribuição do parlamentar como um meio de garantir a liberdade dos eleitores como um meio de escolher entre um amplo aspecto de possibilidades. ${ }^{57}$

53 MAXIMILIANO, Carlos. Commentários à Constituição brasileira de 1891, 1918, p. 304.

54 Outro aspecto de impacto sobre o tema é a importância da mídia em relação à atuação do Parlamento, na medida em que, por vezes, os máximos protagonistas de acontecimentos políticos têm sido alheios ao Parlamento, tanto que a publicidade passou de "meio" a "fim" da atividade política - só se faz o que pode ser difundido, sendo as Câmaras um lugar de encontro entre políticos e jornalistas, estes, muitas vezes, fazendo a pauta parlamentar (GARCÍA MORILLO, Joaquín. El parlamento en la era global. Cuadernos de Derecho Publico, Madrid, n. 1, 1997, p. 77-100). A retribuição é, por vezes, abordada de forma tão pejorativa, que sua defesa envergonha.

${ }^{55} \mathrm{Na}$ democracia ateniense, embora de governo direto-popular, o cidadão que comparecia à Assembleia percebia, por sessão ordinário, uma drachma, ou por uma grande sessão, nove obulos (MAXIMILIANO, Carlos. Commentários à Constituição brasileira de 1891, 1918, p. 305.

${ }^{56}$ Quando, em 1906, houve elevação dos subsídios parlamentares, de nove para quinze mil francos por ano, houve grande reação popular, mesmo assim a lei fora mantida. Nos Estados Unidos, em 1873 houve a aprovação retroativa a 1871, do pagamento de sete mil e quinhentos dólares por ano de salário aos congressistas. Diante dos protestos, o Congresso recuou, mantendo o antigo subsídio, mas em 1907 houve o restabelecimento do referido valor (MAXIMILIANO, Carlos. Commentários à Constituição brasileira de 1891, 1918, p. 304).

${ }^{57}$ BUGALLAL appud DURÁN ALBA, Juan Fernando. Teoría general y régimen jurídico de las incompatibilidades parlamentarias en España. 2001, p. 546. 
GIMENEZ, Charlise P. Colet; VERONESE, Osmar. O papel do vereador no Estado de Direito no Brasil: a defesa dos subsídios como equação democrática. Revista Eletrônica Direito e Política, Programa de Pós-Graduação Stricto Sensu em Ciência Jurídica da UNIVALI, Itajaí, v.10, n.2, $1^{\circ}$ quadrimestre de 2015. Disponível em: www.univali.br/direitoepolitica - ISSN 1980-7791.

\section{CONSIDERAÇÕES FINAIS}

Em suma, mesmo nutrindo imenso respeito a muitos que defendem com boa fé posição contrária a aqui exposta, há muita demagogia em torno da possível gratuidade do exercício de cargos públicos, não sendo conveniente estimulá-la com o simples propósito de guardar sintonia com a opinião pública, até porque, em nome dessa "coerência", muitos inocentes foram queimados em "fogueiras públicas" ou devorados por animais. Calha sublinhar a resposta insuscetível de retificação dada por Talleyrand quando the falaram de um jovem que se propunha a ocupar gratuitamente um cargo: "Ele não pede nada? Então custará muito caro". ${ }^{58}$ Resulta evidente que, na maioria dos casos, potencializa-se o adágio popular de que "o barato sai caro"!

Além disso, por razões que sequer é necessário declinar, não é possível aceitar como parâmetro o período da ditadura militar, época em que os vereadores trabalhavam de graça. Também o vilipêndio a determinada carreira, verdadeira aposta na manutenção dos desqualificados e desmotivados, seja pública ou privada, passa pelo aniquilamento da remuneração. Será que se quer os representantes do povo, no município, sejam a imagem social da miséria?

De outra banda, o exercício de um direito não deve se confundir com seu abuso, de modo que o direito à remuneração, ao lado de outras garantias, deve estar a serviço da liberdade e da independência da instituição parlamentar, nunca ser objeto de enriquecimento (ilícito!), à custa do erário e, por extensão, do contribuinte, ainda mais em uma época em que a administração pública se submete aos princípios da moralidade e eficiência, os quais só são efetivados com uma gestão austera, capaz de servir de exemplo aos demais setores da sociedade. Em razão do exposto, pode-se concluir ser o exercício da vereança brasileira digno de remuneração justa, quer dizer, nem ínfima, nem exagerada.

\footnotetext{
${ }^{58}$ RACIOPPI e BRANELLI apud MAXIMILIANO, Carlos. Commentários à Constituição brasileira
} de 1891, 1918, p. 303. 
GIMENEZ, Charlise P. Colet; VERONESE, Osmar. O papel do vereador no Estado de Direito no Brasil: a defesa dos subsídios como equação democrática. Revista Eletrônica Direito e Política, Programa de Pós-Graduação Stricto Sensu em Ciência Jurídica da UNIVALI, Itajaí, v.10, n.2, $1^{\circ}$ quadrimestre de 2015. Disponível em: www.univali.br/direitoepolitica - ISSN 1980-7791.

\section{REFERÊNCIAS DAS FONTES CITADAS}

ATIENZA, Manuel. El sentido del Derecho. Barcelona: Ariel, 2003.

BERNAL PULIDO, Carlos. El principio de proporcionalidad y los Derechos Fundamentales. Madrid: Centro de Estudios Políticos y Constitucionales, 2005.

BILBAO UBILLOS, Juan María. La eficacia de los Derechos Fundamentales frente a los particulares. Madrid: Centro de Estudios Políticos y Constitucionales, 1997.

BOBBIO, Norberto. A era dos Direitos. Rio de Janeiro: Campus, 1992.

BUGALLAL Y ARAUJO, Gabino. Inviolabilidad parlamentaria. Discurso leído en el acto de su recepción (15.5.1921). Madrid: Real Academia de Ciencias Morales y Políticas, 1921.

CANOTILHO, José Joaquim Gomes. Constituição dirigente e vinculação do legislador: contributo para a compreensão das normas constitucionais programáticas. Coimbra: Coimbra, 1994.

CIOLO, Vittorio di. Il Diritto Parlamentare nella teorie e nella pratica. Aspetti generali e profili strutturali. Milan: Giuffre, 1980.

COUTINHO, Mario Maia. O pai do municipalismo. São Paulo: Patrimônio, 1962.

DI PIETRO, Maria Sylvia Zanella. Direito Administrativo. 18 ed. São Paulo: Atlas, 2005.

DURÁN ALBA, Juan Fernando. Teoría general y régimen jurídico de las incompatibilidades parlamentarias en España. Madrid: Congreso de los Diputados, 2001.

FELDENS, Luciano. Direitos Fundamentais e Direito Penal. Porto Alegre: Livraria do Advogado, 2008.

FERNÁNDEZ-MIRANDA Y CAMPOAMOR, Alfonso. Las prerrogativas parlamentarias de inviolabilidad $y$ inmunidad. In: ALZAGA VILLAAMIL, Oscar (coord.). Comentarios a las leyes políticas. Madrid: Editoriales de Derecho Reunidas, 1989. V. 6.

GARCÍA MORILLO, Joaquín; MARTÍN-RETORTILHO BAQUER, Lorenzo. (orgs.). EI parlamento en la era global. Cuadernos de Derecho Publico, Madrid, n. 1, 1997.

LOJACONO, Giuseppe. Le prerogative dei membri del parlamento. Milano: Giuffré, 1954.

MANZELLA, Andrea. II Parlamento. Bologna: Il Mulino, 1977. 
GIMENEZ, Charlise P. Colet; VERONESE, Osmar. O papel do vereador no Estado de Direito no Brasil: a defesa dos subsídios como equação democrática. Revista Eletrônica Direito e Política, Programa de Pós-Graduação Stricto Sensu em Ciência Jurídica da UNIVALI, Itajaí, v.10, n.2, $1^{\circ}$ quadrimestre de 2015. Disponível em: www.univali.br/direitoepolitica - ISSN 1980-7791.

MAXIMILIANO, Carlos. Commentários à Constituição brasileira de 1891. Rio de Janeiro: Jacinto Ribeiro dos Santos, 1918.

MELO FILHO, Urbano Vitalino de. Direito Municipal em movimento. Belo Horizonte: Del Rey, 1999.

MIRANDA, Jorge. Manual de Direito Constitucional. Coimbra: Coimbra, 1997.

SANTANA, Jair Eduardo. Tratado teórico e prático do vereador. Belo Horizonte: Del Rey, 1998.

SARLET, Ingo Wolfgang. A eficácia dos Direitos Fundamentais. Porto Alegre: Livraria do Advogado, 2006.

SILVA, José Afonso da. Manual do vereador. São Paulo: Malheiros, 2004.

TOSI, Silvano. Diritto Parlamentare. Milano: Dott. A. Giuffré, 1993.

TORON, Alberto Zacharias. Inviolabilidade penal dos vereadores. São Paulo: Saraiva, 2004.

TUMA, Romeu. In: Diário do Senado Federal. Brasília: Senado Federal, 14 de novembro de 2003. Disponível em: <http://www.senado.gov.br/sf/publicacoes/diarios/asp/Diarios.asp?TIP_PAGINA= SENADO\&ANO=2003\&MES=11> Acesso em: 11 jul. 2013.

ZAGREBELSKY, Gustavo. Le immunità parlamentari. Natura e limiti de una garanzia constituzionale. Turin: Einaudi, 1979.

Submetido em: Novembro/2014

Aprovado em: Março/2015 